\title{
Urban commons and urban struggles
}

\author{
Alain Bertho
}

Ida Susser and Stéphane Tonnelat are right to view the question of the urban commons in global cities as a crucial issue. It has precipitated massive urban and often violent struggles. We know that the ideological basis of these fights is very similar from one continent to another. Within the global space there is a global repertory of urban mobilizations and urban riots. Global cities can also be analyzed through the clashes that occur there. Where is this car burning? Beijing, Dakar, Buenos Aires, Tunis, or Mumbai? Where is the "southern world" and where is the "northern one"? When the riot erupts, who can distinguish the political regimes of the country? Against which government is this Molotov cocktail thrown? Against a democratic power or against a dictatorship? All that remains are the national peculiarities of the urban context. Why? First, because residents of global cities are faced with national states, national laws, national polices, in historical contexts. Second, because urban residents are in charge of the question of the people as a nation, as a collective subject in the heart of the cities.

Indeed, what is the root of these fights? Producing a commons does not mean the same thing in two cases. If you talk about producing the commons in immaterial production (including street art), you talk about a population often persecuted by the law and the police: the informal life, informal work, informal trading, informal housing, informal right to the city.
If you talk about the financial accounting of the urban commons, you talk about speculative and financial capital. You talk about the financial and global exploitation of the city of the factories, the city of the inhabitants, and the city of the informal economy. Between these two figures of the city, that of the common creativity and that of the "law and money", the state is no longer in a third position. It no longer guarantees an institutional and public commons, but generally is fighting in fact against the creative city in the name of law and safety.

Under these conditions, all over the world, urban and social movements can take four directions: the impossible common and communal riot, the clash with power, looting, and the alternative expertise and proposal.

1. What urban common can we find in the numerous confrontations of people against people? Almost daily communal riots in India, bloody persecution of Muslims in Burma, bloody anti-Christian riots in Zanzibar, manhunts against Mozambicans in South Africa (the revolt of the townships in 2008) or against Chinese in Algiers, Bolivians in Buenos Aires, gypsies in France or Bulgaria, Africans in Italy ... It is more than the "fear of the small numbers," in the words of Arjun Appadurai (2006), much more local and urban than the alleged and mythical "clash of civilizations". It means the urban territory does not spontaneously produce a subjective commons. The collapse of the 
political strategies of communal representation explains the difficulty in gathering the urban residents together to act as a united people.

2. The second direction that mobilization can take is to clash with power and to riot on all fronts of the urban collective life. In every continent we can see "power riots" (against electric outage), "price riots", "informal trade riots", "housing riots" against expulsion from the popular districts, particularly in the case of informal housing (slums and favelas), ecological riots against urban structures or factories, riots against corruption and land speculation ... Hundreds every year ... In all cases, the gap between the common need and politics is the root of the mob's anger. Victorious revolts are rare.

3. The third direction is urban looting, which is the threat of the "primitive revolt" of Eric J. Hobsbawm (1960). This is a new direction of mobilization in this century. We saw its advent in London in August 2011. In December 2012, Argentinian supermarkets were looted in several towns over several days, causing some deaths.

4. The fourth and last direction that mobilization can take may make it possible to leave the violence of the clash and to enter into communication with the state. Indeed, some mobilizations adopt a strategy of resistance and, in the name of their own expertise, make alternative proposals about urban governance. This fourth direction requires certain conditions. First, mobilizations they need a common subjectivity. The mobilization takes on board the general interest and therefore takes the place of the state, speaks instead of the state. These mobilizations become a rival/partner of the state in producing the commons.

Second, these mobilizations have to produce an expertise on the situation against the state's expertise. The inhabitants of the favela Vila Autódromo in Rio de Janeiro, when they were threatened with expulsion by the urban planning for the Olympics, produced an alternative urban project. The movements that every year fight against the floods in the suburbs of Dakar are currently writing a "White Paper" gathering emergency proposals and structural proposals.
Common subjectivity and popular expertise are the only way to stop, perhaps, the logic of land speculation, and that of "law and money", which threaten their districts and are planning their expulsion "for the future of the city" and "for their safety". This subjective and cognitive mobilization generally builds a self-conscious people not only as a city's people, but also as a national people, conscious of the popular power.

The city is indeed a "strategic territory", as Saskia Sassen (2006) said, because it combines the productive issue, the territorial power issue, and the subjective issue, which are the three dimensions of the urban commons suggested by Ida Susser and Stéphane Tonnelat. But these urban commons are only urban possibilities. Collective mobilization can make them an urban reality. The future is not written in the confrontation between the city of people and the territory of "law and money". The city is today the new terrain of "class struggle": the city is now at the same time the field of material and immaterial production, the field of control, and the field of liberty and democracy. "Occupy" this place? This slogan is not trivial.

Alain Bertho is a professor of anthropology at the Laboratoire Architecture Ville Urbanisme Environnement at the Maison des Sciences de l'Homme Paris Nord. His research interests include relationships between youth and the law, intercommunal forms of governance, and urban mobilizations around housing.

E-mail: Bertho@orange.fr.

\section{References}

Appadurai, Arjun. 2006. Fear of small numbers: A geography of anger. Durham, NC: Duke University Press.

Hobsbawm, Eric J. 1960. Primitive rebels: Studies in archaic forms of social movement in the 19th and 20th centuries. Manchester, UK: Manchester University Press.

Sassen, Saskia. 2006. Territory, authority, rights: From medieval to global assemblages. Princeton, NJ: Princeton University Press. 